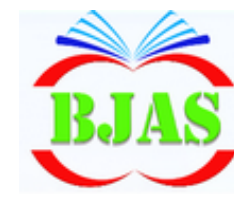

ISSN $1814-5868$
Available online at http://bjas.bajas.edu.iq

https://doi.org/10.37077/25200860.2021.34.1.07

College of Agriculture, University of Basrah

Basrah J. Agric. Sci., 34(1): 67-82, 2021
Basrah Journal

of Agricultural

Sciences

E-ISSN: 2520-0860

\title{
Production of Functional Soft Cheese and Studying its Chemical and Sensory Evaluation Properties
}

\author{
Mariam M. Ghazal ${ }^{1}$, Nawfal A.-A. H. Al-Hilfy ${ }^{2}$ \& Haider I. Ali ${ }^{2 *}$ \\ ${ }^{1}$ College of Education for Women, University of Baghdad, Iraq \\ ${ }^{2}$ Department of Food Sciences, College of Agriculture, University of Basrah, Iraq \\ *Corresponding author email:haiderr_2004@yahoo.com
}

Received 5 May 2020; Accepted 18 July 2020; Available online 13 February 2021

\begin{abstract}
This study design to produce of functional cheese by these parameters: (A) control using raw bovine milk (without any additive), (B) Al-mudhish skim milk powder, (C) Landoz skim milk powder, (D) Regiliat skim milk powder, (E) Spray skimmed milk and 2\% inulin and 2\% modified starch were added to skim milk powder. The evaluation of chemical tests were performed including estimating moisture, protein, fat, carbohydrates, ash, total acidity percentage and $\mathrm{pH}$, and sensory evaluation properties during refrigerated storage at the periods $(1,7,14,21$ and 28) days. The results showed that the functional soft cheese from Landoz milk powder with ( $2 \%$ inulin and $2 \%$ modified starch) was have a higher percent of moisture and carbohydrates during the last period of storage (28) days compared to the control. The production of soft cheese by using Landoz milk powder with a mixture of prebiotic and probiotic has got the highest sensory features.
\end{abstract}

Keywords: Skim milk, Functional food, Probiotics.

\section{Introduction}

Liquid milk is one of the basic requirements to make cheese. Bovine milk is considered a perfect source for many proteins that are necessary for the human body. Therefore, bovine milk is considered the main product in the world. Since its production participates by around $85-90 \%$ from the total global production and most of the biological effects of the active peptides in milk have a positive effect on general health. Milk is considered natural semi-integrated food material due it consists of most of the necessary nutritional compounds (Dziuba \& Dziuba, 2014; Balthazar et al., 2017). Due of the fluctuation in fresh milk production, its shortage in many countries including Iraq and in addition to the expectation of the World Health Organization of the increase of demand for milk by $25 \%$ in 2025 (Muehlhof et al., 2013).

Milk Powder has become an essential part of dairy products manufacturing and spray drying has a big role in this. By evaporating the milk until dryness, so that solid fine materials in milk molecules are concentrated. So it has become easier to transfer and increased its shelf life. In addition to the various uses of powdered milk in a large number of applications compared to liquid milk such as being a fermented dairy products. Al-samahi et al. (2011) explained that the spray drying method is used to dry milk, eggs, some liquid, and semi-liquid food so that the material becomes powdered particles. Soft cheese was produced from 
concentrating the total solid material from the reconstructed milk and by adding Calcium Chloride $0.02 \%$; purified culture of therapeutic bacteria mixture (Olivera et al., 2012). The modified starch role is a basic requirement for the growth of the therapeutic bacteria Lactobacillus and Bifidobacteria (Charalapoulos et al., 2002).

So, this study was aimed to produce functional soft cheese with the probiotic bacteria mixture Lactobacillus acidophilus and Bifibacterium animals by adding mixture prebiotic Inulin and, modified starch.

\section{Materials \& Methods}

\section{Materials}

Functional soft cheese formulation were prepared by using the following reconstructed milk 12\%. Raw milk and type of milk powder, which are available in the local market, were used [Al-mudhish (Omani brand), Landoz (Holland brand), Regiliat (French brand) and Spray (Ireland brand)] within the validity period. By using a method described by Al-Dahan (1983) with some modification, reconstructed milk $12 \%$, prebiotics (Inlin 2\%) and Modified starch ( $2 \%)$ and the mixture was added to the milk and treated thermally at $63^{\circ} \mathrm{C}$ for $30 \mathrm{~min}$ and was left to cool down to $31^{\circ} \mathrm{C}$, then the therapeutic starter $2 \%$ was added, followed by adding the microbial Meito rennet $1 \%$ which was supplied by the Japanese company Meito SANGYO CO. LTD. Then the curd was cut and the whey was drained. $2 \%$ salt was added followed by compressing, filling and cool storage for $(1,7,14,21$ and 28$)$ days.

\section{Experimental and statistical analysis}

Chemical tests were performed at the used milk as mentioned before (Lacto flash) (Table 1) and the functional cheese which have included moisture (Abd El-Salam, 2015) fat (Gerber method, Hussien et al., 2016), protein (Abdulahdei et al., 2017), carbohydrates (Abd El-Salam, 2015), ash, acidity, and $\mathrm{pH}$ value estimated using the method described by Hussien et al. (2016) through dipping the electrodes directly in the milk.

\section{Statistical analysis}

The studied parameters were done by using Complete Randomized Design (CRD) to analyse the inspected parameters, their effects on the different qualities, comparing the significant differences between the average values and choosing the least difference $(\mathrm{P}<0.05)$ by using a premade program $(\mathrm{LSD})$.

\section{Sensory evaluation}

Sensory evaluation for the treated cheese product was performed by the professors and students of the post-graduate study in the food science department of University of Basrah and the staff of research and development of Abu Ghareeb dairy company in Baghdad for the days 1, 7, 14, 21 and 28 of storage. Tendegree scale was used for every sensory quality which has included colour, flavour, texture, taste, and appearance. Degree (5) was the boundary between acceptance and rejection of the quality.

\section{Results \& Discussion}

\section{The chemical analysis composition of milk}

It was noticed from the (Table 1) which represent the chemical analysis of the used milk for manufacturing, the existence of significant differences in the structure of the prepared milk for cheese manufacturing with the parameters (A, B, C, D and E) represented by the percent of the moisture, protein, fat, carbohydrates, $\mathrm{pH}$ value and acidic titration. The moisture percent was high which can be attributed to the quality of used milk for 
manufacturing or the breed of the animal and its nutrition and manufacturing conditions.

The results of the chemical analysis were compatible with the results of Ibrahim \& Doosh (2016), where the moisture was $90.2 \%$, titratable acidity 0.16 and protein $(3.25 \%)$ which is considered within the normal range as well as with what Abdulahdei et al. (2017) found. The protein was $3.3 \%$, acidic titration 0.16 , and moisture percentage $90.4 \%$ for the sorted milk. The reason for high moisture percent was the lack of total solid materials due to the reduction of fact and the results of Visser (1991) have shown the same thing. He pointed out that the role of fat reduction will lead to increasing the moisture content for the manufactured Cheddar from sorted milk. This can be explained due to an increase in the susceptibility of the protein in the powdered milk to connect with water. In addition to the changes in like nature of the protein as a result of drying processes, which also inhibits the enzymes that add thermal stability to the milk and concentrate the sorted milk by 9 $50 \%$ weight/weight as a solid material.

Table (1): Chemical parameter for type of milk powder *.

\begin{tabular}{lcccccc}
\hline $\begin{array}{c}\text { Chemical } \\
\text { content }\end{array}$ & $\begin{array}{c}\text { Moisture } \\
\%\end{array}$ & $\begin{array}{c}\text { Protein } \\
\%\end{array}$ & $\begin{array}{c}\text { Fat } \\
\%\end{array}$ & $\begin{array}{c}\text { Carbohydrates } \\
\%\end{array}$ & $\begin{array}{c}\text { Acidic } \\
\text { titration }\end{array}$ & $\mathrm{pH}$ \\
\hline Milk & 88.7 & 3.3 & 3.0 & 5.0 & 0.15 & 6.3 \\
\hline Al-mudhish B & 90.2 & 3.6 & 0.1 & 4.5 & 0.16 & 6.3 \\
\hline Landoz C & 89.2 & 3.8 & 0.1 & 5.8 & 0.16 & 6.4 \\
\hline Regiliat D & 87.7 & 4.7 & 0.1 & 7.0 & 0.15 & 6.3 \\
\hline Spray E & 89.1 & 4.0 & 0.1 & 6.0 & 0.16 & 6.3 \\
\hline
\end{tabular}

\section{*Three repetition rate.}

\section{Moisture}

The results from the table (2) have shown a decrease in the moisture content during the storage period due to evaporating processes and a decrease in the $\mathrm{pH}$ value which is compatible with what were found by and Hana et al. (2007), Al-sharaji (2009) and Alsarayi (2017). Those studies have indicated with the decrease in the moisture content during the storage period which is consistent with what was found by Sabikhi et al. (2014) that the moisture content has decreased while manufacturing mature aging cheese due to evaporation during the aging process. In addition to an increase in the amount of Lactic acid due to starter bacteria and prebiotic stimulant activities and decrease in the $\mathrm{pH}$ value during the aging process. In the processing of the soft cheese with inulin and modified starch mixture additive, a higher moisture rate was recorded compared to the control parameter which contains no additive due to the susceptibility of the aqueous colloids including inulin to bind with water, 
since hydroxyel $(\mathrm{OH})$ in its composition have a role in increasing its ability to bind in water compared to the control parameter which contains no additive, this was noticed by Yahyavi \& Kalajahi (2014) where the additive inulin in the produced vita cheese from the sorted milk has led to increasing in the moisture content in the control cheese.
While Dantas et al. (2016) have indicated the reason of the decrease in the moisture content in the manufactured soft cheese sample using L. casei Zhang probiotic stimulant due to the decrease in the $\mathrm{pH}$ value and the increase in the titration acidity as a result of bio-stimulant bacteria activity and the consumption of the left out lactic sugar.

Table (2): Moisture percent (\%) of functional soft cheese which produced from type of milk powder during storage for 28 day.

\begin{tabular}{|c|c|c|c|c|c|}
\hline \multirow{2}{*}{$\begin{array}{l}\text { Pype of milk } \\
\text { Teriod/day }\end{array}$} & \multicolumn{5}{|c|}{ Moisture (\%) } \\
\hline & 1 & 7 & 14 & 21 & 28 \\
\hline A. Control parameter & $63.63 \pm 0.26 a$ & $63.60 \pm 0.32 \mathrm{a}$ & $63.57 \pm 1.06 \mathrm{a}$ & $63.00 \pm 0.31 \mathrm{a}$ & $62.00 \pm 0.91 \mathrm{~b}$ \\
\hline $\begin{array}{l}\text { B. Al-mudhish } \\
\text { 2\%inulin }\end{array}$ & $63.72 \pm 0.43 a$ & $63.70 \pm 0.50 \mathrm{a}$ & $63.50 \pm 3.23 \mathrm{a}$ & $62.50 \pm 1.54 \mathrm{a}$ & $62.00 \pm 3.87 \mathrm{a}$ \\
\hline $\begin{array}{l}\text { Al-mudhish } \\
2 \% \text { modified starch }\end{array}$ & $68.90 \pm 4.94 \mathrm{a}$ & $68.71 \pm 0.23 \mathrm{a}$ & $68.67 \pm 1.11 \mathrm{a}$ & $68.50 \pm 1.27 \mathrm{a}$ & $67.00 \pm 1.19 \mathrm{a}$ \\
\hline $\begin{array}{l}\text { Almudhish } 2 \% \text { inulin } \\
2 \% \text { modified starch }\end{array}$ & $62.00 \pm 2.38 \mathrm{a}$ & $61.50 \pm 3.69 a$ & $61.00 \pm 1.92 \mathrm{a}$ & $60.00 \pm 0.20 \mathrm{a}$ & $59.00 \pm 3.63 \mathrm{a}$ \\
\hline C. Landoz $2 \%$ inulin & $69.20 \pm 0.01 \mathrm{a}$ & $69.00 \pm 4.60 \mathrm{a}$ & $68.40 \pm 3.15 \mathrm{a}$ & $67.00 \pm 4.74 \mathrm{a}$ & $66.00 \pm 1.64 \mathrm{a}$ \\
\hline $\begin{array}{l}\text { Landoz } 2 \% \text { modified } \\
\text { starch }\end{array}$ & $65.47 \pm 0.19 a$ & $65.20 \pm 0.81 \mathrm{a}$ & $65.00 \pm 1.09 \mathrm{a}$ & $64.00 \pm 0.89 a$ & $63.50 \pm 0.37 b$ \\
\hline $\begin{array}{l}\text { Landoz } 2 \% \text { inulin } \\
2 \% \text { modified starch }\end{array}$ & $69.43 \pm 0.92 \mathrm{a}$ & $69.11 \pm 1.54 \mathrm{a}$ & $69.00 \pm 0.43 a$ & $68.00 \pm 0.63 \mathrm{a}$ & $68.00 \pm 0.29 a$ \\
\hline D. Regiliat $2 \%$ inulin & $63.25 \pm 4.12 \mathrm{a}$ & $63.23 \pm 3.93 \mathrm{a}$ & $63.07 \pm 3.46 \mathrm{a}$ & $61.67 \pm 4.96 \mathrm{a}$ & $61.13 \pm 4.26 \mathrm{a}$ \\
\hline $\begin{array}{l}\text { Regiliat 2\%modified } \\
\text { starch }\end{array}$ & $63.18 \pm 4.83 \mathrm{a}$ & $63.00 \pm 4.69 \mathrm{a}$ & $63.00 \pm 1.3 \mathrm{a}$ & $63.00 \pm 3.75 \mathrm{a}$ & $62.11 \pm 0.88 \mathrm{a}$ \\
\hline $\begin{array}{l}\text { Regiliat } 2 \% \text { inulin and } \\
\text { modified starch }\end{array}$ & $63.00 \pm 0.46 \mathrm{a}$ & $63.00 \pm 0.38 \mathrm{a}$ & $63.00 \pm 0.78 \mathrm{a}$ & $62.00 \pm 0.91 b$ & $62.00 \pm 0.49 b$ \\
\hline E. Spray $2 \%$ inulin & $63.25 \pm 0.53 a$ & $63.20 \pm 2.02 \mathrm{a}$ & $63.07 \pm 1.85 \mathrm{a}$ & $62.81 \pm 0.32 \mathrm{a}$ & $62.00 \pm 4.30 \mathrm{a}$ \\
\hline $\begin{array}{l}\text { Spray 2\%modified } \\
\text { starch }\end{array}$ & $63.21 \pm 3.81 \mathrm{a}$ & $63.17 \pm 4.34 \mathrm{a}$ & $63.00 \pm 1.54 \mathrm{a}$ & $61.81 \pm 0.30 \mathrm{a}$ & $61.00 \pm 2.21 \mathrm{a}$ \\
\hline $\begin{array}{l}\text { Spray } 2 \% \text { inulin } \\
2 \% \text { modified starch }\end{array}$ & $63.21 \pm 1.61 \mathrm{a}$ & $63.15 \pm 0.65 \mathrm{a}$ & $63.00 \pm 4.49 \mathrm{a}$ & $62.00 \pm 0.36 \mathrm{a}$ & $62.00 \pm 1.01 \mathrm{a}$ \\
\hline
\end{tabular}

a, b: Different letters within the same column indicates to the distinguished differences between the parameters by distinguishable

It was noticed that the loss rate in the moisture content in the samples manufactured using milk (Regiliat and Spray) is higher than the other samples due to the increase in the acidity and decrease in the $\mathrm{pH}$ value which decrease in the moisture content led to sensory changes on the level $(\mathrm{P}<0.05)$ in the led to the decrease in the moisture. In addition, the moisture content is inversely proportional with duration of aging. Even so, the moisture rate has stayed within the range specified by the Iraqi standard quality. The 
other solid content and gradually in the protein, fat, salt and ash content.

\section{Protein}

Table (3) explains the percentage of protein in control cheese transactions that exceeded other cheese transactions adding fat replacements (Inulin and modified starch) have made the protein the dominant part among the total solid materials. It can be noticed from the statistical analysis the existence of distinguishable differences $(\mathrm{P}<0.05)$ and it couldn't be noticed the existence of such differences in protein percentage among the parameters with Inulin after manufacturing immediately. This can be justified due to the ability of Inulin to bond with water, hence increasing the moisture content and decreasing the total solid materials including protein and this is compatible with what Yahyavi \& Kalajahi (2014) found. The effect of adding Inulin was noticed by noticing the decrease in the protein percentage in low fat vita cheese. While Hussien et al. (2016) found an increase in the rate of protein when Monterey cheese was manufactured without the use of bio-stimulant strains mixture due to the decrease in the moisture content during the aging period

Table (3): Protein percent (\%) of functional soft cheese which produced from type of milk powder.

\begin{tabular}{lccccc}
\hline \multirow{2}{*}{$\begin{array}{c}\text { period/day } \\
\text { Type of mitk }\end{array}$} & \multicolumn{5}{c}{ Protein $(\%)$} \\
\cline { 2 - 6 } & 1 & 7 & 14 & 21 & 28 \\
\hline A. Control parameter & $18.20 \pm 2.19 \mathrm{a}$ & $18.80 \pm 1.87 \mathrm{a}$ & $18.81 \pm 1.68 \mathrm{a}$ & $19.00 \pm 1.89 \mathrm{a}$ & $20.01 \pm 2.15 \mathrm{a}$ \\
\hline B. Al-mudhish 2\%Inulin & $19.61 \pm 1.67 \mathrm{a}$ & $22.61 \pm 1.87 \mathrm{a}$ & $23.15 \pm 1.69 \mathrm{a}$ & $23.30 \pm 1.12 \mathrm{a}$ & $23.45 \pm 2.06 \mathrm{a}$ \\
\hline $\begin{array}{l}\text { Al-mudhish 2\%modified } \\
\text { starch }\end{array}$ & $19.10 \pm 1.71 \mathrm{a}$ & $19.77 \pm 2.10 \mathrm{a}$ & $20.07 \pm 1.64 \mathrm{a}$ & $20.32 \pm 2.04 \mathrm{a}$ & $21.32 \pm 1.79 \mathrm{a}$ \\
\hline $\begin{array}{l}\text { Almudhish 2\% Inulin } \\
2 \% \text { modified starch }\end{array}$ & $18.17 \pm 2.01 \mathrm{a}$ & $22.77 \mathrm{a} \pm 2.21 \mathrm{ab}$ & $23.98 \pm 1.98 \mathrm{a}$ & $23.99 \pm 1.85 \mathrm{a}$ & $24.00 \pm 1.75 \mathrm{a}$ \\
\hline C.Landoz 2\% Inulin & $18.98 \pm 1.99 \mathrm{a}$ & $19.00 \pm 1.88 \mathrm{a}$ & $19.27 \pm 2.08 \mathrm{a}$ & $20.50 \pm 1.60 \mathrm{a}$ & $21.50 \pm 2.18 \mathrm{a}$ \\
\hline $\begin{array}{l}\text { Landoz 2\%modified } \\
\text { starch }\end{array}$ & $18.17 \pm 1.97 \mathrm{a}$ & $19.07 \pm 1.75 \mathrm{~b}$ & $20.00 \pm 1.83 \mathrm{a}$ & $21.53 \pm 1.62 \mathrm{a}$ & $22.00 \pm 1.75 \mathrm{a}$ \\
\hline $\begin{array}{l}\text { Landoz 2\% Inulin } \\
2 \% \text { modified starch }\end{array}$ & $18.27 \pm 1.63 \mathrm{a}$ & $18.90 \pm 2.01 \mathrm{a}$ & $19.00 \pm 1.85 \mathrm{a}$ & $19.05 \pm 1.60 \mathrm{a}$ & $20.00 \pm 1.65 \mathrm{a}$ \\
\hline D.Regiliat 2\% inulin & $15.92 \pm 1.73 \mathrm{a}$ & $22,25 \pm 2.09 \mathrm{a}$ & $22.42 \pm 1.65 \mathrm{a}$ & $23.03 \pm 1.90 \mathrm{a}$ & $23.50 \pm 1.81 \mathrm{a}$ \\
\hline Regiliat 2\%modified starch & $22.29 \pm 1.76 \mathrm{a}$ & $22.44 \pm 1.90 \mathrm{a}$ & $23.07 \pm 1.66 \mathrm{a}$ & $23.50 \pm 2.17 \mathrm{a}$ & $20.55 \pm 2.00 \mathrm{a}$ \\
\hline $\begin{array}{l}\text { Regiliat 2\% inulin } \\
2 \% \text { modified starch }\end{array}$ & $23.20 \pm 1.83 \mathrm{a}$ & $24.00 \pm 1.76 \mathrm{a}$ & $24.20 \pm 1.68 \mathrm{a}$ & $24.50 \pm 1.70 \mathrm{a}$ & $24.30 \pm 1.84 \mathrm{a}$ \\
\hline E. Spray 2\% inulin & $22.22 \pm 1.92 \mathrm{a}$ & $22.25 \pm 2.16 \mathrm{a}$ & $22.29 \pm 1.87 \mathrm{a}$ & $22.77 \pm 1.67 \mathrm{a}$ & $23.18 \pm 1.92 \mathrm{a}$ \\
\hline Spray 2\%modified starch & $22.22 \pm 1.82 \mathrm{a}$ & $22.26 \pm 1.79 \mathrm{a}$ & $23.05 \pm 2.09 \mathrm{a}$ & $23.50 \pm 1.72 \mathrm{a}$ & $23.70 \pm 1.74 \mathrm{a}$ \\
\hline $\begin{array}{l}\text { Spray 2\% Inulin } \\
2 \% \text { modified starch }\end{array}$ & $22.22 \pm 1.97 \mathrm{a}$ & $22.25 \pm 2.21 \mathrm{a}$ & $23.00 \pm 1.89 \mathrm{a}$ & $23.40 \pm 2.07 \mathrm{a}$ & $23.50 \pm 2.14 \mathrm{a}$ \\
\hline
\end{tabular}

$\mathrm{a}$ and $\mathrm{b}$ : Different letters within the same column indicates to the distinguished differences between the parameters by distinguishable $\mathrm{a}$ and $\mathrm{b}$ : 
Bergamini et al. (2006) have explained that L. acidophilus bacteria have an effect on secondary protein degradation by increasing the low weight molecular compounds like the peptides and free amino acids which depend on the used bio-stimulant strains during manufacturing and the type of the produced cheese. While Olivera et al. (2012) have indicated the increase in the rate of degradation of protein in the therapeutic cheese was due to the use of mixed cultures of bio-stimulant strains that produce enzymes which act on increasing the rate of degradation of protein, hence increasing the peptides and free fatty acids. The parameters with added prebiotic (Inulin and modified starch) have had increase protein rate compared with the controlled parameter which can be explained on the basis on that substitution made the cheese mostly filled with protein, lactose, salts and a little percentage of fat.

\section{Fat}

Table (4) explains the percentage of fat in control cheese transactions that exceeded other cheese transactions Inulin has added $2 \%$ modified starch $2 \%$ as it stood at the end of the storage period (15.15\%) for the treatment of control; for the rest of the transactions, cheese Almudhish, Landoz, Regiliat and Spray cheese were 2.99, 2.80, 2.23 and 2.00 ) $\%$ respectively for the same period. As well as the present results indicate are close to what AOAC (2016) found Ibrahim \& Doos (2016). The same rate of addition to inulin, but it differed from what found for soft cheese, which amounted to $18.0 \%$. This difference is due to because the milk used in the study was dried skim milk. The transactions of cheese varied by addition modified starch as it reached compared with the control treatment, but agreed with Ibrahim \& Doosh (2016) when dealing with cheese Low fat by adding inulin, which is a substitute for fat as it occupies a large part of the volume of processed cheese and increases the concentration of solids, and also the results of the study agreed with what he showed Abd El- Salam (2015) by adding fat substitutes in soft, low-fat cheese, the fat percentage decreased in the resulting cheese compared to cheese control during the storage period, an increase in all treatments was observed in the percentage of fat.

\section{Carbohydrate}

Table (5) shows the percentage of carbohydrates in cheese samples for control and cheese treatment with the addition of Inulin $2 \%$ modified starch $2 \%$ and mixture of inulin and modified starch $2 \%$ which indicate the presence of significant differences in the first day of storage, as they were respectively for the control treatment $1.66 \%$ and due the cheese samples treatments produced from skim milk dried surprisingl, type

Landoz, Regiliat, Spray for the same period by adding the mixture of prebiotics $(13.93,10.35,11.83$ and $16.59 \%)$ while varied in the last storage period to record values forthe treatment of control which reached $0.94 \%$ with a significant difference from the rest of the treatments for the cheese mixture, which was respectively for the same types $8.97,10.00$ (9.7 and 10.71\%). 
Table (4): Fat percent (\%) of functional soft cheese which produced from type of milk powder.

\begin{tabular}{lccccc}
\hline \multirow{2}{*}{ Milk type } & \multicolumn{5}{c}{ Fat $(\%)$} \\
\cline { 2 - 6 } & 1 & 7 & 14 & 21 & 28 \\
\hline A. Control parameter & $14.80 \pm 2.72 \mathrm{a}$ & $15.13 \pm 2.15 \mathrm{a}$ & $15.15 \pm 1.19 \mathrm{a}$ & $15.15 \pm 3.19 \mathrm{a}$ & $15.15 \pm 2.11 \mathrm{a}$ \\
\hline B.Almudhish 2\%inulin & $1.17 \pm 0.14 \mathrm{a}$ & $1.77 \pm 0.18 \mathrm{a}$ & $1.77 \pm 0.14 \mathrm{a}$ & $2.52 \pm 0.11 \mathrm{~b}$ & $3.00 \pm 0.19 \mathrm{c}$ \\
\hline $\begin{array}{l}\text { Almudhish 2\% modified } \\
\text { starch }\end{array}$ & $2.07 \pm 0.18 \mathrm{a}$ & $2.13 \pm 0.23 \mathrm{a}$ & $2.37 \pm 0.14 \mathrm{a}$ & $2.50 \pm 0.20 \mathrm{a}$ & $2.60 \pm 0.14 \mathrm{ab}$ \\
\hline $\begin{array}{l}\text { Almudhish 2\% inulin } \\
\text { 2\%modified starch }\end{array}$ & $2.00 \pm 0.19 \mathrm{a}$ & $2.00 \pm 0.14 \mathrm{a}$ & $2.13 \pm 0.13 \mathrm{a}$ & $2.99 \pm 0.20 \mathrm{~b}$ & $2.99 \pm 0.11 \mathrm{~b}$ \\
\hline C.Landoz 2\% inulin & $1.31 \pm 0.12 \mathrm{a}$ & $2.11 \pm 0.19 \mathrm{a}$ & $2.50 \pm 0.14 \mathrm{c}$ & $2.80 \pm 0.13 \mathrm{~b}$ & $2.55 \pm 0.16 \mathrm{c}$ \\
\hline Landoz 2\% modified starch & $.110 \pm 0.15 \mathrm{a}$ & $.122 \pm 0.16 \mathrm{a}$ & $.177 \mathrm{a} \pm 0.11 \mathrm{ab}$ & $1.94 \pm 0.15 \mathrm{c}$ & $2.00 \pm 0.17 \mathrm{c}$ \\
\hline $\begin{array}{l}\text { Landoz 2\% inulin } \\
\text { and \%2 modified starch }\end{array}$ & $.119 \pm 0.12 \mathrm{a}$ & $.130 \pm 0.14 \mathrm{a}$ & $.160 \pm 0.13 \mathrm{ab}$ & $2.00 \mathrm{a} \pm 0.15 \mathrm{ab}$ & $2.00 \pm 0.18 \mathrm{a}$ \\
\hline D.Regiliat 2\% inulin & $1.47 \pm 0.19 \mathrm{a}$ & $1.51 \pm 0.16 \mathrm{a}$ & $1.51 \pm 0.17 \mathrm{a}$ & $2.00 \pm 0.20 \mathrm{a}$ & $2.40 \pm 0.15 \mathrm{ab}$ \\
\hline $\begin{array}{l}\text { Regiliat 2\% modified } \\
\text { starch }\end{array}$ & $1.52 \pm 0.12 \mathrm{a}$ & $1.60 \pm 0.15 \mathrm{a}$ & $2.00 \pm 0.13 \mathrm{a}$ & $2.30 \pm 0.11 \mathrm{a}$ & $2.33 \mathrm{a} \pm 0.21 \mathrm{a}$ \\
\hline $\begin{array}{l}\text { Regiliat 2\% inulin } \\
\text { and \%2 modified starch }\end{array}$ & $2.00 \pm 0.11 \mathrm{a}$ & $2.00 \pm 0.18 \mathrm{a}$ & $2.20 \pm 0.17 \mathrm{a}$ & $2.23 \pm 0.15 \mathrm{a}$ & $2.50 \pm 0.16 \mathrm{ab}$ \\
\hline $\begin{array}{l}\text { E.Spray 2\% inulin } \\
\text { Spray 2\% modified starch }\end{array}$ & $1.33 \pm 0.24 \mathrm{a}$ & $1.40 \pm 0.14 \mathrm{a}$ & $2.00 \pm 0.20 \mathrm{a}$ & $2.00 \pm 0.12 \mathrm{a}$ & $2.04 \pm 0.13 \mathrm{a}$ \\
\hline $\begin{array}{l}\text { 2\% } \\
\text { Spray 2 \% inulin and 2 \% } \\
\text { modified starch }\end{array}$ & $1.40 \pm 0.12 \mathrm{a}$ & $1.41 \pm 0.16 \mathrm{a}$ & $2.24 \pm 0.18 \mathrm{~b}$ & $2.60 \pm 0.11 \mathrm{~b}$ & $2.80 \pm 0.14 \mathrm{~b}$ \\
\hline
\end{tabular}

Different letters within a single column indicate that there are significant differences between transactions at a significant level $(\mathrm{p}<0.05)$.

In general, a significant decrease in all treatments is observed in the percentage of carbohydrates recorded and this decrease is attributed to the role of the activity of microorganisms in converting lactose sugar into lactic acid on the one hand The other side is the loss of part of the carbohydrate, with whey being clear during storage periods (McSweeny \& Fox, 2013).

\section{Ash}

Table (6) reveals the per cent of ash content in the samples of processed cheeses, as they were in cheese treatment control at first and last day was 1.17 and $1.9 \%$ respectively, and compared to cheese samples manufacturing with mixture prebiotic that were straight for milk cheese samples, mudhish, landoz, regiliat, and spray was $1.34,1.45,1.33$ and $1.24 \% 1.24 \%$ ) at the first day respectively, and it was 2.00 , $2.50,2.50$ and $3.30 \%$ respectively these results indicate significant differences between the transactions at probability level $(\mathrm{P}<0.05)$. It increased in all transactions due to the rise in content ash to lower moisture content and progress for ripening increase the per cent of solid components conform to those results with the study of Ali et al. (2013) when manufacturing three models of cheese similar to ash of the per cent for all manufactured models attributing the reason of a loss in its moisture content as the stages of ripeness progress and between Abd El-Gawad \& Ahmed (2011) that the reason for the continued decrease in the 
moisture of waxed cheese It returns to evaporation during the ripening stages, which affects the balance of other components, including ash. The results of Ali et al. (2013) showed an increase in the ash content of cheese like an ashary the factory is laboratory tested using strains of biological enhancers St. lactis and Bif. animals as the maturity progresses as a result of the loss in humidity and the increase in the percentage of solid components, Al-sarayi (2017) indicated The same results when making Monterey cheese. Results of the study agreed with Ibrahim \& Doosh (2016) there are significant differences in the proportion of ash in the transactions.

Table (5): Carbohydrate percent (\%) of functional soft cheese which produced from type of milk powder.

\begin{tabular}{|c|c|c|c|c|c|}
\hline \multirow{2}{*}{ Milk type } & \multicolumn{5}{|c|}{ Carbohydrates (\%) } \\
\hline & 1 & 7 & 14 & 21 & 28 \\
\hline A. Control parameter & $1.66 \pm 0.05 b$ & $0.72 \pm 0.08 \mathrm{a}$ & $0.72 \pm 0.04 \mathrm{a}$ & $0.1 \pm 0.02 b$ & $0.94 \pm 0.03 b$ \\
\hline $\begin{array}{l}\text { B. } \\
\text { Almudhish } 2 \% \text { inulin }\end{array}$ & $13.94 \pm 1.00 \mathrm{a}$ & $10.3 \pm 1.41 \mathrm{a}$ & $9.96 \pm 1.37 \mathrm{a}$ & $9.68 \pm 1.54 \mathrm{a}$ & $9.55 \pm 1.34 \mathrm{a}$ \\
\hline $\begin{array}{l}\text { Almudhish2\% modified } \\
\text { starch }\end{array}$ & $8.38 \pm 1.44 a$ & $7.79 \pm 0.99 a$ & $7.19 \pm 1.59 \mathrm{a}$ & $6.38 \pm 1.23 b$ & $6.38 \pm 1.03 \mathrm{~b}$ \\
\hline $\begin{array}{l}\text { Almudhish } 2 \% \text { inulin } \\
\text { and } 2 \% \text { modified starch }\end{array}$ & $16.59 \pm 2.18 \mathrm{a}$ & $12.23 \pm 1.77 \mathrm{a}$ & $11.29 \pm 1.10 \mathrm{a}$ & $11.22 \pm 1.57 \mathrm{a}$ & $10.71 \pm 1.08 \mathrm{a}$ \\
\hline C.Landoz $2 \%$ inulin & $9.27 \pm 1.18 \mathrm{a}$ & $8.39 \pm 0.43 \mathrm{a}$ & $8.28 \pm 1.82 \mathrm{a}$ & $7.7 \pm 1.26 \mathrm{~b}$ & $6.65 \pm 1.08 \mathrm{~b}$ \\
\hline $\begin{array}{l}\text { Landoz 2\% modified } \\
\text { starch }\end{array}$ & $13.93 \pm 2.68 \mathrm{a}$ & $13.02 \pm 1.01 \mathrm{a}$ & $11.67 \pm 1.08 \mathrm{a}$ & $10.33 \pm 0.95 b$ & $\begin{array}{c}10.00 \pm 1.69 \\
\mathrm{~b}\end{array}$ \\
\hline $\begin{array}{l}\text { Landoz } 2 \% \text { inulin } \\
\text { and } 2 \% \text { modified starch }\end{array}$ & $9.88 \pm 1.37 \mathrm{a}$ & $9.32 \pm 0.61 \mathrm{a}$ & $8.90 \pm 1.48 \mathrm{~b}$ & $8.90 \pm 1.04 \mathrm{~b}$ & $7.41 \pm 1.40 \mathrm{~b}$ \\
\hline D. Regiliat $2 \%$ inulin & $18.19 \pm 2.35 \mathrm{a}$ & $11.41 \pm 1.76$ & $11.4 \pm 1.31 \mathrm{~b}$ & $11.3 \pm 1.59 \mathrm{~b}$ & $\begin{array}{c}10.72 \pm 1.69 \\
\mathrm{~b}\end{array}$ \\
\hline $\begin{array}{l}\text { Regiliat } 2 \% \text { modified } \\
\text { starch }\end{array}$ & $10.78 \pm 1.28 \mathrm{a}$ & $10.69 \pm 1.73 a$ & $9.65 \pm 1.38 \mathrm{~b}$ & $8.8 \pm 1.71 \mathrm{a}$ & $7.51 \pm 1.15$ \\
\hline $\begin{array}{l}\text { Regiliat 2\%inulin } \\
\text { and } 2 \% \text { modified starch }\end{array}$ & $10.35 \pm 1.32 \mathrm{a}$ & $9.52 \pm 0.44 \mathrm{a}$ & $9.11 \pm 1.80 \mathrm{a}$ & $9.00 \pm 1.53 \mathrm{a}$ & $8.97 \pm 1.44 \mathrm{a}$ \\
\hline E. Spray $2 \%$ inulin & $11.88 \pm 1.22$ & $11.69 \pm 1.33 \mathrm{a}$ & $11.18 \pm 1.74 \mathrm{a}$ & $10.95 \pm 0.99 \mathrm{a}$ & $10.6 \pm 1.00 \mathrm{a}$ \\
\hline $\begin{array}{l}\text { Spray } 2 \% \text { modified } \\
\text { starch }\end{array}$ & $11.85 \pm 1.20 \mathrm{a}$ & $11.66 \pm 1.42 \mathrm{a}$ & $10.62 \pm 1.30 \mathrm{a}$ & $10.45 \pm 1.60 \mathrm{a}$ & $10.41 \pm 0.95 \mathrm{a}$ \\
\hline $\begin{array}{l}\text { Spray 2\% inulin } \\
\text { and } 2 \% \text { modified starch }\end{array}$ & $11.83 \pm 1.20 \mathrm{a}$ & $11.69 \pm 1.42 \mathrm{a}$ & $10.23 \pm 1.30 \mathrm{a}$ & $10.00 \pm 1.60 \mathrm{a}$ & $9.7 \pm 1.50 \mathrm{a}$ \\
\hline
\end{tabular}

Characters pain within a single column indicate that there are significant differences between transactions at a significant level $(\mathrm{p}<0.05)$ 
Table (6): Ash percent (\%) of functional soft cheese which produced from type of milk powder.

\begin{tabular}{llllll}
\hline & \multicolumn{5}{c}{ Ash $(\%)$} \\
Milk type & 1 & 7 & 14 & 21 & 28 \\
\cline { 2 - 6 } & & & & \\
A.Control parameter & $1.71 \pm 0.14 \mathrm{a}$ & $1.75 \pm 0.26 \mathrm{a}$ & $1.75 \pm 0.14 \mathrm{a}$ & $1.90 \pm 0.16 \mathrm{a}$ & $1.90 \pm 0.15 \mathrm{a}$ \\
\hline B.Almudhish 2\% inulin & $1.56 \pm 0.26 \mathrm{a}$ & $1.62 \pm 0.18 \mathrm{a}$ & $1.62 \pm 0.16 \mathrm{a}$ & $2.00 \pm 0.28 \mathrm{a}$ & $2.00 \pm 0.30 \mathrm{a}$ \\
\hline $\begin{array}{l}\text { Almudhish2\% modified } \\
\text { starch }\end{array}$ & $1.55 \pm 0.19 \mathrm{a}$ & $1.60 \pm 0.21 \mathrm{a}$ & $1.70 \pm 0.14 \mathrm{a}$ & $2.30 \pm 0.27 \mathrm{a}$ & $2.31 \pm 0.14 \mathrm{~b}$ \\
\hline $\begin{array}{l}\text { Almudhish 2\% inulin } \\
\text { and2\% modified starch }\end{array}$ & $1.24 \pm 0.30 \mathrm{a}$ & $1.50 \pm 0.28 \mathrm{a}$ & $1.60 \pm 0.31 \mathrm{a}$ & $1.80 \pm 0.29 \mathrm{a}$ & $3.30 \pm 0.22 \mathrm{~b}$ \\
\hline $\begin{array}{l}\text { C.Landoz 2\% inulin } \\
\text { Landoz 2\% modified starch }\end{array}$ & $1.33 \pm 0.29 \mathrm{a}$ & $1.49 \pm 0.25 \mathrm{a}$ & $1.56 \pm 0.31 \mathrm{a}$ & $2.20 \pm 0.31 \mathrm{~b}$ & $2.50 \pm 0.15 \mathrm{~b}$ \\
\hline $\begin{array}{l}\text { Landoz 2\% inulin } \\
\text { and2\% modified starch }\end{array}$ & $1.23 \pm 0.25 \mathrm{a}$ & $1.37 \pm 0.30 \mathrm{a}$ & $1.50 \pm 0.26 \mathrm{a}$ & $2.40 \pm 0.32 \mathrm{~b}$ & $2.59 \pm 0.22 \mathrm{~b}$ \\
\hline $\begin{array}{l}\text { D.Regiliat 2\% inulin } \\
\text { Regiliat2\% modified starch }\end{array}$ & $2.23 \pm 0.19 \mathrm{a}$ & $2.27 \pm 0.15 \mathrm{a}$ & $2.28 \pm 0.29 \mathrm{a}$ & $2.40 \pm 0.14 \mathrm{a}$ & $2.50 \pm 0.27 \mathrm{a}$ \\
\hline $\begin{array}{l}\text { Regiliat2\%inulin } \\
\text { and 2\% modified starch }\end{array}$ & $1.45 \pm 0.16 \mathrm{a}$ & $1.48 \pm 0.25 \mathrm{a}$ & $1.49 \pm 0.22 \mathrm{a}$ & $2.00 \pm 0.21 \mathrm{~b}$ & $2.50 \pm 0.14 \mathrm{~b}$ \\
\hline $\begin{array}{l}\text { E.Spray2\% inulin } \\
\text { Spray2\% modified starch }\end{array}$ & $1.34 \pm 0.30 \mathrm{a}$ & $1.51 \pm 0.25 \mathrm{a}$ & $1.53 \pm 0.20 \mathrm{a}$ & $2.00 \pm 0.28 \mathrm{~b}$ & $2.60 \pm 0.28 \mathrm{~b}$ \\
\hline $\begin{array}{l}\text { Spray 2\% inulin and 2\% } \\
\text { modified starch }\end{array}$ & $1.34 \pm 0.28 \mathrm{a}$ & $1.50 \pm 0.15 \mathrm{a}$ & $1.53 \pm 0.14 \mathrm{a}$ & $2.00 \pm 0.26 \mathrm{~b}$ & $2.00 \pm 0.15 \mathrm{~b}$ \\
\hline
\end{tabular}

Characters pain within a single column indicate that there are significant differences between transactions at a significant level $(\mathrm{p}<0.05)$.

The modified starch $2 \%$ indicated El-Baz (2013)that the high ash content in these transactions is due to a role alternative fat additives as well as a decrease in the moisture content and the associated increase in the percent of substances solid which ash is one of its components, which is reflected in the increase in ash content

\section{pH}

Table (7) displays the $\mathrm{pH}$ value of functional soft cheese samples made from milk powder as they reached first day highest value for treatment cheese of Regiliat with mixture of prebiotic inulin and modified starch at 6.070 compared to the treatment of control cheese which reached at the same period 5.493 and the lower vale was to the treatment of Landoz mixture of prebiotic inulin and modified starch at value 5.100 in the same period of storage, and from that we found that the $\mathrm{pH}$ value recorded a decrease in its values and the treatment recorded highest value 6.100 at the end day of storage to the samples of Spray with inulin adding, when the lower value was to the treatment of Almudhish by added inulin 
5.000 compared to the control treatment at value 5.300 and the results of the statistical analysis which indicated that there were significant differences at the probability level ( $\mathrm{P}<0.05)$ for cheese models and affected type, period of storage and interaction between the treatment, and the reasons for this are due to activity of initiator and bio stimulant bacteria, consumption of residual lactose sugar, and high sorcery acidity. The reason for the gradual rise in the acidity as indicated by Al-sharaji et al. (2009) when making cheese Ripe Monterey with the ripening period, the remaining lactose sugar in cheese will be transformed into lactic acid by the lactic fermentation of the starter bacteria.

Table (7): pH value percent (\%) of functional soft cheese which produced from type of milk powder.

\begin{tabular}{lrrrrc}
\hline \multirow{2}{*}{ Milk type } & \multicolumn{5}{c}{$\mathrm{pH}$ value } \\
\cline { 2 - 6 } & 1 & 7 & 14 & 21 & 28 \\
\hline A. Control parameter & 5.493 & 5.300 & 5.300 & 5.200 & 5.097 \\
\hline B. Almudhish 2\% inulin & 5.483 & 5.200 & 5.130 & 5.080 & 5.000 \\
\hline Almudhish 2\% modified starch & 5.387 & 5.073 & 5.067 & 5.067 & 5.043 \\
\hline $\begin{array}{l}\text { Almudhish 2\% inulin and2 \% modified } \\
\text { starch }\end{array}$ & 5.233 & 5.220 & 5.200 & 5.117 & 5.033 \\
\hline C.Landoz 2\% inulin & 5.483 & 5.413 & 5.167 & 5.100 & 5.087 \\
\hline Landoz 2\% modified starch & 5.370 & 5.200 & 5.130 & 5.110 & 5.100 \\
\hline Landoz 2\% inulin and2\% modified starch & 6.033 & 6.033 & 5.880 & 5.800 & 5.100 \\
\hline D. Regiliat 2\% inulin & 5.200 & 5.133 & 5.133 & 5.067 & 5.040 \\
\hline Regiliat2\% modified starch & 6.067 & 6.000 & 6.000 & 5.867 & 5.833 \\
\hline Regiliat2\%inulin and 2\% modified starch & 6.133 & 6.070 & 5.967 & 5.900 & 5.870 \\
\hline E.Spray2\% inulin & 6.100 & 6.033 & 5.900 & 5.880 & 5.660 \\
\hline Spray2\% modified starch & 5.933 & 5.503 & 5.500 & 5.100 & 5.000 \\
\hline $\begin{array}{l}\text { Spray 2\% inulin and 2\% modified starch } \\
\text { L.S.D }\end{array}$ & 6.530 & 5.900 & 5.897 & 5.833 & 5.803 \\
\hline
\end{tabular}

The results of the study were consistent with the findings of Sabbagh et al. (2010) found that the cause of the rise the titratable acidity of ripening cheese is that it contains high numbers of bacteria boosters. As a result of the availability of nutrients in the cheese environment, which consume lactose sugar and lactic acid production. The previous results were consistent with what Hussien et al. (2016) found during his making with and without Monterey Cheese. Using mixtures of strains of biological enhancers, the reasons for 
that gradual decrease in the number were attributed $\mathrm{pH}$ to the persistence of lactic acid bacteria by consuming lactose sugar and esters and producing lactic acid and other organic acids. Xin et al. (2015) found $\mathrm{pH}$ decrease occurs with a progression ripening in ripe Cheddar cheese has been explained by the decrease in moisture and an increase in bacterial activity during ripening and consumption of lactose sugar remaining in cheese and the production of lactic acid. The $\mathrm{pH}$ values are experiencing a decrease in their values, during the storage periods, and the differences in these values are significant between control treatment and coefficients added inulin and axon starch, the first and last day were consecutive.

\section{Titratable acidity}

Table (8) demonstrates the percent of titratable acidity of processed cheese models as it reached the highest value $(0.387)$ at the first day for treatment of control and Almudhish with modified starch, compared with a lower value 0.167 for treatment of Regiliat with a mixture of prebiotic inulin and modified starch. And at the end of period storage reached treatment of Spray with added mixture of prebiotic inulin and modified starch highest value 0.42 compared with the lower value 0.200 for Landoz with mixture added inulin and modified Starch compared with value 0.303 for control treatment at the same period of storage, respectively. The results of the statistical analysis showed significant differences at the probability level $(\mathrm{P}<0.05)$ of the model's cheese, the reasons for this are due to a decrease in the moisture content, as well as an increase in the amount of lactic acid produced from the activity of the starter bacteria, the bio booster, and the decrease of the $\mathrm{pH}$ as the storage period progressed, results was agree with Al-sharaji et al. (2009) that found during his manufacture of ripe Monterrey cheese, indicating that the reason the gradual increase in the titratable acidity with the progression of the ripening period is due to the transformation of the remaining lactose sugar in cheese to lactic acid, during the process of lactic fermentation of the initiator bacteria. And agree with Al-sarayi (2017) as the results indicated a gradual rise during the ripening stages of Monterrey cheese.

\section{Sensory Evaluation}

Table (9) explains that the functional soft cheese for the parameter of added $2 \%$ inulin and modified starch and mixture showed no differences in the first storage period and the $7^{\text {th }}$ day, and from observing the values. The results refer that the best result were it found in a day 21 and 28 was parameter of the soft cheese mixture of Landoz milk powder with the control parameter, as these additives had a role in improving characteristics of flavour, texture, taste, colour and acceptability of the consumer, and describe the cheese in the preferred white colour at consumer, these results were inconsistent with Alnemr et al. (2013), when he referred to the deterioration of characteristics. The sensual cottage cheese is low in fat and free from fatty alternatives.

Additions changed the environment of cheese, during Industrialization and maturity, which affect the modification of $\mathrm{pH}$ values, heat and efficacy, water activity (Ganesan et al., 2007). 
Table (8): The per cent of titrable acidity of functional soft cheese which produced from type of milk powder.

\begin{tabular}{lrrrrc}
\hline \multicolumn{1}{c}{ Period / day } & \multicolumn{5}{c}{ Treatable acidity (\%) } \\
\cline { 2 - 6 } Milk type & 1 & 7 & 14 & 21 & 28 \\
\hline A. Control parameter & 0.387 & 0.303 & 0.400 & 0.400 & 0.410 \\
\hline B. Almudhish 2\% inulin & 0.400 & 0.400 & 0.400 & 0.387 & 0.377 \\
\hline Almudhish2\% modified starch & 0.400 & 0.400 & 0.387 & 0.387 & 0.387 \\
\hline $\begin{array}{l}\text { Almudhish 2\% inulin and2 \% modified } \\
\text { starch }\end{array}$ & 0.400 & 0.387 & 0.387 & 0.370 & 0.350 \\
\hline C.Landoz 2\% inulin & 0.400 & 0.400 & 0.387 & 0.383 & 0.333 \\
\hline Landoz 2\% modified starch & 4.00 & 4.00 & 0.387 & 0.387 & 0.380 \\
\hline Landoz 2\% inulin and2\% modified starch & 0.200 & 0.200 & 0.190 & 0.140 & 0.130 \\
\hline D. Regiliat 2\% inulin & 0.400 & 0.387 & .0 .380 & 0.360 & 0.360 \\
\hline Regiliat2\% modified starch & 0.387 & 0.373 & 0.360 & 0.360 & 0.360 \\
\hline Regiliat2\%inulin and 2\% modified starch & 0.370 & 0.360 & 0.360 & 0.200 & 0.167 \\
\hline E.Spray2\% inulin & 0.370 & 0.370 & 0.370 & 0.360 & 0.360 \\
\hline Spray2\% modified starch & 0.400 & 0.400 & 0.390 & 0.370 & 0.363 \\
\hline Spray 2\% inulin and 2\% modified starch & 0.420 & 0.400 & 0.400 & 0.390 & 0.383 \\
\hline
\end{tabular}

L.S.D $\quad 0.028$

Table (9): Sensory evaluation of functional soft cheese which produced from type of milk powder.

\begin{tabular}{|c|c|c|c|c|c|c|c|}
\hline \multirow[t]{2}{*}{ Type of milk } & \multirow[t]{2}{*}{ Period/day } & \multicolumn{6}{|c|}{ Sensor Characteristics } \\
\hline & & $\begin{array}{l}\text { Colour } \\
10 \\
\end{array}$ & $\begin{array}{l}\text { Flavor } \\
10\end{array}$ & Texture & $\begin{array}{l}\text { Taste } \\
10\end{array}$ & $\begin{array}{l}\text { acidity } \\
10\end{array}$ & $\begin{array}{l}\text { Appearance } \\
10\end{array}$ \\
\hline \multirow[t]{5}{*}{ Control } & 1 & 4.00 & 4.00 & 5.33 & 5.33 & 5.00 & 6.00 \\
\hline & 7 & 5.00 & 5.00 & 5.00 & 6.00 & 5.00 & 5.00 \\
\hline & 14 & 5.00 & 5.00 & 5.00 & 5.00 & 5.00 & 5.00 \\
\hline & 21 & 5.00 & 5.00 & 5.00 & 5.00 & 5.00 & 4.00 \\
\hline & 28 & 5.00 & 5.00 & 5.00 & 5.00 & 5.00 & 4.00 \\
\hline Almudhish & 1 & 7.00 & 7.00 & 6.00 & 6.00 & 5.00 & 5.00 \\
\hline \multirow[t]{4}{*}{$2 \%$ inulin } & 7 & 7.00 & 6.00 & 5.00 & 5.00 & 5.00 & 5.00 \\
\hline & 14 & 6.00 & 6.00 & 5.00 & 5.00 & 5.00 & 5.00 \\
\hline & 21 & 6.00 & 6.00 & 5.00 & 5.00 & 5.00 & 5.00 \\
\hline & 28 & 6.00 & 5.00 & 5.00 & 5.00 & 5.00 & 4.00 \\
\hline Almudhish & 1 & 6.00 & 5.00 & 5.00 & 5.00 & 5.00 & 5,00 \\
\hline \multirow[t]{4}{*}{$2 \%$ modified starch } & 7 & 6.00 & 5.00 & 5.00 & 5.00 & 5.00 & 5.00 \\
\hline & 14 & 6.00 & 4.33 & 4.00 & 5.00 & 4.00 & 5.00 \\
\hline & 21 & 6.00 & 5.00 & 4.00 & 5.00 & 4.00 & 5.00 \\
\hline & 28 & 5.00 & 5.00 & 4.00 & 4.00 & 4.00 & 4.00 \\
\hline Almudhish2\%inulin & 1 & 6.00 & 6.00 & 6.00 & 5.00 & 5.00 & 5.00 \\
\hline
\end{tabular}


Ghazal et al. / Basrah J. Agric. Sci., 34(1): 67-82, 2021

\begin{tabular}{|c|c|c|c|c|c|c|c|}
\hline \multirow{4}{*}{$\begin{array}{l}\text { and } 2 \% \text { modified } \\
\text { starch }\end{array}$} & 7 & 5.00 & 6.00 & 6.00 & 5.00 & 4.00 & 5.00 \\
\hline & 14 & 5.00 & 5.00 & 5.00 & 5.00 & 5.00 & 5.00 \\
\hline & 21 & 6.00 & 5.00 & 5.00 & 5.00 & 5.00 & 4.00 \\
\hline & 20 & 6.00 & 5.00 & 5.00 & 5.00 & 4.00 & 4.00 \\
\hline \multirow[t]{5}{*}{ Landoz2\%inulin } & 1 & 9.00 & 9.00 & 9.00 & 9.00 & 9.00 & 9.67 \\
\hline & 7 & 9.00 & 9.00 & 9.00 & 9.00 & 9.00 & 9.67 \\
\hline & 14 & 8.00 & 9.00 & 9.00 & 9.00 & 9.00 & 9.67 \\
\hline & 21 & 8.00 & 8.00 & 8.00 & 9.00 & 9.00 & 9.00 \\
\hline & 28 & 8.00 & 8.00 & 8.00 & 8.00 & 9.00 & 9.00 \\
\hline Landoz & 1 & 8.00 & 8.00 & 8.00 & 9.67 & 8.00 & 9.00 \\
\hline \multirow[t]{4}{*}{$2 \%$ modified starch } & 7 & 8.00 & 7.00 & 8.00 & 8.00 & 8.00 & 8.00 \\
\hline & 14 & 8.00 & 7.00 & 9.00 & 9.67 & 8.00 & 9.00 \\
\hline & 21 & 9.00 & 8.33 & 8.00 & 8.00 & 8.00 & 8.33 \\
\hline & 28 & 9.00 & 7.00 & 8.00 & 8.00 & 8.00 & 9.00 \\
\hline \multirow{5}{*}{$\begin{array}{l}\text { Landoz } 2 \% \text { inulin } \\
\text { and } 2 \% \text { modified } \\
\text { starch }\end{array}$} & 1 & 9.67 & 9.00 & 9.67 & 9.67 & 8.00 & 9.00 \\
\hline & 7 & 9.00 & 8.00 & 9.67 & 9.00 & 7.00 & 8.00 \\
\hline & 14 & 9.00 & 9.00 & 9.00 & 9.00 & 6.00 & 9.00 \\
\hline & 21 & 9.00 & 7.33 & 8.00 & 7.33 & 6.33 & 8.33 \\
\hline & 28 & 9.00 & 9.00 & 9.00 & 8.00 & 8.00 & 9.00 \\
\hline \multirow[t]{5}{*}{ Regiliat2\%inulin } & 1 & 5.00 & 5.00 & 5.00 & 5.00 & 4.00 & 5.00 \\
\hline & 7 & 5.00 & 5.00 & 5.00 & 5.00 & 4.00 & 5.00 \\
\hline & 14 & 5.00 & 6.00 & 4.00 & 4.00 & 4.00 & 5.00 \\
\hline & 21 & 5.00 & 6.00 & 4.00 & 4.00 & 4.00 & 5.00 \\
\hline & 28 & 6.00 & 5.00 & 5.00 & 4.00 & 4.00 & 5.00 \\
\hline Regiliat & 1 & 5.00 & 5.00 & 6.00 & 4.00 & 4.00 & 5.00 \\
\hline \multirow[t]{4}{*}{$2 \%$ modified starch } & 7 & 5.00 & 5.00 & 6.00 & 5.00 & 4.00 & 5.00 \\
\hline & 14 & 5.00 & 4.00 & 5.00 & 5.00 & 4.00 & 5.00 \\
\hline & 21 & 4.00 & 4.00 & 5.00 & 4.00 & 4.00 & 5.00 \\
\hline & 28 & 4.00 & 5.00 & 5.00 & 4.00 & 4.00 & 5.00 \\
\hline \multirow{5}{*}{$\begin{array}{l}\text { Regiliat2\%inulin } \\
\text { and } 2 \% \text { modified } \\
\text { starch }\end{array}$} & 1 & 5.00 & 6.00 & 6.00 & 6.00 & 5.00 & 5.00 \\
\hline & 7 & 6.00 & 6.00 & 6.00 & 5.00 & 5.00 & 5.00 \\
\hline & 14 & 5.00 & 5.00 & 5.00 & 4.00 & 4.00 & 5.00 \\
\hline & 21 & 4.00 & 5.00 & 5.00 & 5.00 & 4.00 & 5.00 \\
\hline & 28 & 4.00 & 5.00 & 5.00 & 5.00 & 4.00 & 5.00 \\
\hline \multirow[t]{5}{*}{ Spray2\%inulin } & 1 & 8.00 & 7.00 & 8.00 & 7.00 & 7.00 & 9.67 \\
\hline & 7 & 8.00 & 7.00 & 8.00 & 6.00 & 7.00 & 9.67 \\
\hline & 14 & 9.00 & 7.00 & 7.00 & 6.00 & 7.00 & 9.00 \\
\hline & 21 & 8.00 & 7.00 & 6.00 & 5.00 & 6.00 & 8.00 \\
\hline & 28 & 8.00 & 6.00 & 6.00 & 5.00 & 6.00 & 8.00 \\
\hline Spray2\%modified & 1 & 7.00 & 6.00 & 5.00 & 5.00 & 7.00 & 8.00 \\
\hline \multirow[t]{4}{*}{ Starch } & 7 & 7.00 & 6.00 & 5.00 & 6.00 & 6.00 & 7.00 \\
\hline & 14 & 8.00 & 6.00 & 6.00 & 6.00 & 6.00 & 7.00 \\
\hline & 21 & 7.00 & 7.00 & 6.00 & 5.00 & 6.00 & 6.00 \\
\hline & 28 & 7.00 & 6.00 & 6.00 & 5.00 & 7.00 & 6.00 \\
\hline Spray2\% inulin and & 1 & 7.00 & 6.00 & 5.00 & 5.00 & 7.00 & 8.00 \\
\hline \multirow[t]{4}{*}{$2 \%$ modified starch } & 7 & 7.00 & 6.00 & 5.00 & 6.00 & 6.00 & 7.00 \\
\hline & 14 & 8.00 & 6.00 & 6.00 & 6.00 & 6.00 & 7.00 \\
\hline & 21 & 7.00 & 7.00 & 6.00 & 5.00 & 6.00 & 6.00 \\
\hline & 28 & 7.00 & 6.00 & 6.00 & 5.00 & 7.00 & 6.00 \\
\hline L.S.D & & 0.71 & 0.72 & 0.70 & 0.69 & 0.71 & 0.68 \\
\hline
\end{tabular}




\section{Conclusion}

The production of soft cheese by using Landoz milk powder with a mixture of prebiotic and probiotic has given the highest sensory advantages as well as chemical composition, which included protein, fat, moisture, ash, carbohydrate and acidity compared to other types of milk used in the study.

\section{Acknowledgments}

The authors' gratitude to the Department of Food Science, College of Agriculture, University of Basrah for the support this research work.

\section{Conflicts of interest}

The authors declare that they have no conflict of interests.

N. A.-A. Hussain orcid.org/0000-0002-37920906

H. I. Ali: orcid.org/0000-0001-5185-6093

\section{References}

Abd El- Salam, B. A. (2015). Effect of milk fat replacement with vegetable oil and/or whey protein concentrate on microstructure, texture, and sensory characteristics of fresh soft cheese. International Journal of Dairy Sciences, 10, 117-125. https://doi.org/10.3923/ijds.2015.117.125

Abd El-Gawad, M.A.M. \& Ahmed, V.S. (2011). Cheese yield as affected by some parameters review. Acta Scientiarum Polonorum Technologia Alimentaria, 10, 131-153. https://www.food.actapol.net/pub/1_2_2011.pdf

Abdulahdei, I. M., Omar, R. H., \& Doosh, K. S. (2017). The study of the effect of using inulin as fat replacer in the physico-chemical and sensory properties of low energy cheddar cheese. Al-Anbar Journal Veterinary Sciences, 10, 167-176. https://www.anbarjvs.edu.iq/the-study-of-theeffect-of-using-inulin-as-fat-replacer-in-thephysico-chemical-and-sensory-properties-of-lowenergy-cheddar-cheese/
Al-Dahan, A. (1983). Manufacturing of Types Cheese in the World. Dar Alhekma Printing. Mosul, 589pp. (In Arabic).

Ali, M.; Shaban, A. KH. \& Saleh, M. H. (2013). The production of semi Oshari cheese by using therapeutic bacteria and compared with some species of local some areas in the northern Iraq. Tikrit Journal Agriculture Sciences, 13, 20-24. (In Arabic).https://www.iasj.net/iasj?func=fulltext\&aId $=65190$

Alnemr, T. M., Abd El- Razek, A. M., Hasan, H. M. A., \& Massoud, M. I. (2013). Improving of karish cheese by using enhanced technological texturizing inulin. Alexandria Journal Agricultural Research, 58 ,

173-181. http://agr.p.alexu.edu.eg/Data/Sites/1/magazine/201 3,58,2/2013.58.2.173-181.pdf

Al-samahi, S. K. S., Shatta, A.A.-B., \& Yousif, K. M. (2011). Foods Technology. Dar-al masera, Amman. 848pp.

https://www.massira.jo/content/\%D8\%AA\%D9\%8 3\%D9\%86\%D9\%88\%D9\%84\%D9\%88\%D8\%AC $\% \mathrm{D} 9 \% 8 \mathrm{~A} \% \mathrm{D} 8 \% \mathrm{~A} 7-$ \%D8\%A7\%D9\%84\%D8\%A7\%D8\%BA\%D8\%B0 \%D9\%8A\%D8\%A9

Al-sarayi, H. M. A. (2017). Study of chemical and microbial changes of probiotic Monterey cheese. M. Sc. Thesis, University of Baghdad, 97pp. (In Arabic).

Al-sharaji, S. H., Abboud, S. J., \& Shaker, K. A. (2009). Using of Calotropics procerca in acceleration ripening of Monterey cheese. Jordanian Journal of Agricultural Sciences, 5, 556578. (In Arabic). https://journals.ju.edu.jo/JJAS/article/viewFile/869/ 863?target=_blank

AOAC: Association of Official Analytical Chemist's (2016). Official Method Analysis. 20th edition., Washington, 2, 3172pp. http://www.eoma.aoac.org/methods/info.asp?ID=16 264

Balthazar, C. F., Pimentel, T. C., Ferrão, L. L., Almada, C. N., Santillo, A., Albenzio, M., Mollakhalili, N., Mortazavian, A. M., Nascimento, J. S., \& Silva, M. C. (2017). Sheep milk: Physicochemical characteristics and relevance for functional food development. Comprehensive 
Reviews in Food Science Food Safety, 16, 247262.https://doi.org//10.1111/1541-4337.12250

Bergamini, C. V., Hynes, E. R., \& Zalazar, C. A. (2006). Influence of probiotic bacteria on theproteolysis profile of semi-hard cheese. International Dairy Journal, 16, 856-866. https://doi.org/10.1016/j.idairyj.2005.09.004

Charalapoulos, D., Wang, R., Pandiella, S. S., \& Webb, C. (2002). Application of cereals and cereal components in functional foods: A review. International Journal Food Microbiology, 79, 131141. https://doi.org/10.1016/S0168-1605(02)001873

Dantas, A. B., Jesus, V. F., Silva, R., Almada, C. N., Esmerino, E. A., Cappato, L. P., Silva, M. C., Raices, R. S. L., Cavalcanti, R. N., Carvalho, C. C., Sant'Ana, A. S., Bolini, H. M. A., Freitas, M. Q., \& Cruz, A. G. (2016). Manufacture of probiotic minas frescal cheese with Lactobacillus casei Zhang. Journal Dairy Science, 99, 1830.https://doi.org/10.3168/jds.2015-9880

Dziuba, B., \& Dziuba, M. (2014). Milk proteinsderived bioactive peptides in dairy molecular, biological , and methodological aspects. Acta Scientiarum Polonorum Technologia Alimentaria, 13, 5. https://doi.org/10.17306/J.AFS.2014.1.1

El-Baz, A. (2013). The use of inulin as a dietary fiber in the production of synbiotic UF-soft cheese. Journal of Food and Dairy Sciences, 4, 663-677. https://doi.org/10.21608/jfds.2013.72121

Ganesan, B., Stuart, M. R., \& Weimer, B. C. (2007). Carbohydrate starvation causes a metabolically active but nonculturable state in Lactococcus lactis. Applied Environmental Microbiology, 73, 24982512. https://doi.org/10.1128/AEM.01832-06

Hana, S. S., Ayied, A. Y. \& Abdullradah, A. J. (2007). Effect of some environmental factors on milk acetone level and their relationship with milk yield and some contents. Basrah Journal of Agricultural Sciences, 20, 65-75. (In Arabic). https://www.iasj.net/iasj?func=fulltext\&aId=56079

Hussien, N. A., Alrikabi, A. K. \& Khalaf, A. A. (2016). Increasing of conjugated linoleic acid concentration in Monterey cheese by using co-culture. Thi Qar University Journal for Agricultural Research, 5, 128.

(In

Arabic).
https://www.iasj.net/iasj?func=fulltext\&aId=12094 4

Ibrahim, D. \& Doosh, K. S. (2016). Effect of using whey protein concentrates on physicochemical, rheological and sensory properties of low-fat Iraqi soft cheese. Al Furat Journal of Agricultural Sciences, 8, 216-229. (In Arabic). https://www.iasj.net/iasj?func=fulltext\&aId=11585 6

Muehlhoff, E., Bennett, A ., \& Mcmahon, D. (2013). Milk Dairy Products in Human Nutrition. FAO, Rome, 376pp. https://doi.org/10.1111/14710307.12124

Olivera, M. E. G. D., GarciaII, E. F., QueirogaI, R. D. C. R., \& De Souza, E. L. (2012). Technological, physicochemical and sensory characteristics of a Brazilian semi-hard goat cheese (coalho) with added probiotic lactic acid bacteria. Sciences Agriculture, $\quad 69, \quad 370-379$. https://doi.org/10.1590/S0103-90162012000600005

Sabbagh, N., Gheisari, H. R., \& Aminlari, M. (2010). Monitoring the chemical and microbiological changes during ripening of Iranian probiotic low-fat white cheese. American Journal Animal Veterinarian Sciences, 5, 249-257. https://doi.org/10.3844/ajavsp.2010.249.257

Sabikhi, L., Kumar M. H. S., \& Mathur, B. N. (2014). Bifidobacterium bifidum in probiotic Edam cheese: influence on cheese ripening. Journal of Food Science Technology, 51, 3902-3909. https://doi.org/10.1007/s13197-013-0945-7

Visser, J. (1991). Factors Affecting the Rheological and Fracture Properties of Hard and Semi-hard Cheese. 49-61 In Walstra, P. (Ed.). Rheological and Fracture Properties of Cheese. International Dairy Federation, Brussels, Belgium, 67pp.

Xin, J. H., Ya, S. M., \& Yu. G. G. (2015). Influence of Lactobacillus casei LC2W on the proteolysis and aroma compounds of Cheddar cheese during the ripening period. CyTA-Journal Food, 13, 464-471. https://doi.org/10.1080/19476337.2014.1003099

Yahyavi, F., \& Kalajahi, S. E. M. (2014). A study of the possibility of low- fat feta cheese production using dietary fiber. Advance Environmental Biology, $\quad 8, \quad 1245-\quad 1249$. http://www.aensiweb.com/old/aeb/special $\% 205 \% 2$ 02014/1245-1249.pdf 
Ghazal et al. / Basrah J. Agric. Sci., 34(1): 67-82, 2021

\section{إنتاج الجبن الطري الوظيفي ودراسة خصائصه الكيميائية والحسية \\ مريم مال الله غزال1 وحيدر ابراهيم علي2 ونوفل عبدالامير حسين الحلفي2 \\ 1 اكلية التربية للبنات، جامعة بغداد، العرلق}

\section{2قسم علوم الاغذية، كلية الزراعة، جامعة البصرة، العراق}

المستخلص: تم تصميم هذه الدراسة لإنتاج جبن وظيفي باستخدام هذه ألمعايير (أ) عينة السيطرة باستخدام حليب الأبقار الخام (بدون أي اضافة) ، (ب) حليب المدهش الفرز الخالي من الدهن، (ج) حليب لاندوز الفرز الخالي من الدهن، (د) حليب ريجليه الفرز الخالي من الدهن، (E) حليب سبري الفرز الخالي من الدهن مع اضافة 2 ٪ من الأنيولين و 2 \% من النشا المعدل والمضافة إلى انواع الحليب الفرز الخالي من الدهن. تم دراسة التركيب الكيميائية لأنواع الجبن الوظيفي والمتضدن تقدير الرطوبة، والبروتين، والدهون، والكربوهيدرات، والرماد، ونسبة الحموضة الكلية، والاس الهيدروجيني pH، فضلا عن ذلك تم اجراء التقييم الحسي أثناء الخزن المبرد وخلال فترات 1، 7، 14، 21 و 28 يومًا. اذ أوضحت النتائج أن الجبن الطري الوظيفي المصنع من حليب Landoz الفرز الخالي من الدهن مع (2\% أنولين و 2\% نشا معدل) كان يحتوي على أعلى نسبة من الرطوبة والكربوهيدرات خلال الفترة الخزن الأخيرة (28 يومًا) مقارنة بمجموعة السيطرة، وان إنتاج الجبن الطري باستخدام حليب Landoz الفرز الخالي من الدهن مع مزيج من السابق الحيوي والمعزز الحيوي لديه أعلى الميزات الحسية. الكلمات المفتاحية: حليب فرز، غذاء وظيفي ، معزز حيوي. 